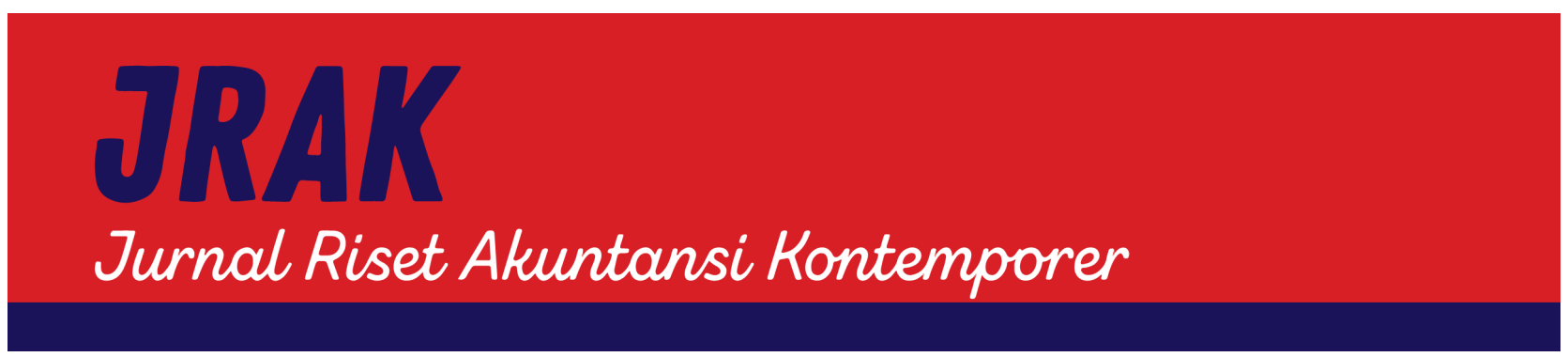

\title{
MEDIATION OF PROFITABILITY ON CORPORATE SOCIAL RESPONSIBILITY TO FIRM VALUE
}

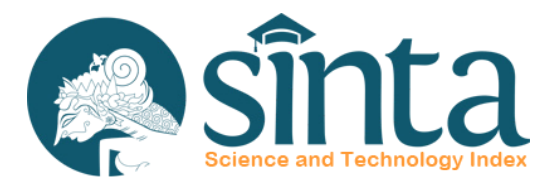

https://journal.unpas.ac.id/index.php/jrak/index

Siti Nurul Faizah ${ }^{1} \bowtie$, Dharma Tintri Ediraras ${ }^{2}$

${ }^{1,2}$ Universitas Gunadarma

$\triangle$ nfaizah915@gmail.com

Jl. Margonda Raya No. 100, Depok 16424, Jawa Barat Depok, Indonesia

\section{Article Info}

History of Article

Received: 24/08/2021

Revised: 13/09/2021

Published: 18/10/2021

Jurnal Riset Akuntansi Kontemporer

Volume 13, No. 2, October 2021, Page. 51-58

ISSN 2088-5091 (Print)

ISSN 2597-6826 (Online)

Keywords: economic perfomance; environment perfomance; social perfomance; profitability; firm value

\begin{abstract}
The study aims to test and analyze the influence of CSR as measured by Economic Performance, Environmental Performance, and Social Performance on Firm Value measured using Tobin's Q with profitability as a mediation variable. The object of this research is the information communication sector, health sector, agricultural sector, electricity sector, and real estate sector, and they were analyzed with statistical methods used is Partial Least Square (PLS). The results of this study showed that Economic Performance, Environmental Performance, and Social Performance had no effect on Return on Equity (ROE) and Tobin's Q, while Return on Equity (ROE) had an effect on Tobin's Q either.
\end{abstract}

\section{INTRODUCTION}

Communities and economies around the world have faced such an unprecedented surprise. The existence of the Covid-19 virus started in Wuhan in December 2019 until its unexpected spread to Indonesia. Covid-19 has been traced as the cause of outbreaks of infectious respiratory diseases through direct or aerial contact. On January 30,2020, WHO designated Covid-19 as a state of a severe public health emergency. The virus affects many things that have never been imagined before starting from the implementation of lockdown, PSBB (Largescale social restrictions), the implementation of work from home for companies, and education. The policy is implemented to reduce the impact of Covid-19 transmission, its Economic needs are a very influential and important factor for daily life. The situation of the Covid-19 pandemic that occurred in Indonesia has resulted in many sectors that are paralyzed and severely affected by the existence of this easily transmitted virus, one of which is in the field of transportation and warehousing industry. Especially in terms of flight transportation, due to the implementation of PSBB by the government, many customers continue to cancel flight schedules due to the outbreak, but some airlines still fly even though the seats are not full. This incident allows the government to reorganize and formulate new policies so that the industry can survive this pandemic era. 


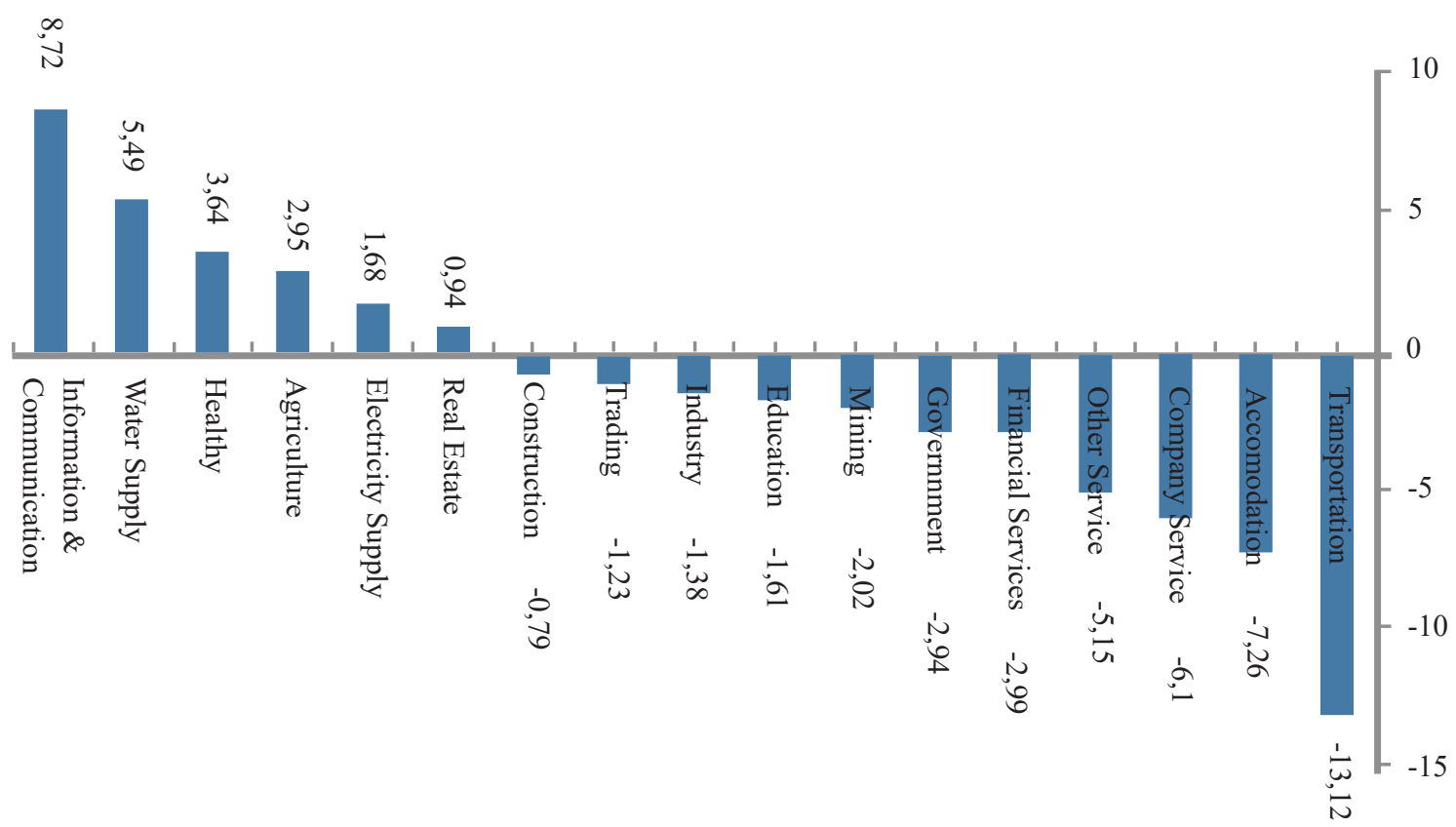

Figure 1. Indonesia's Economic Growth Graph Quarter 1 - 2021 By Business Field

But not all sectors of companies in Indonesia have decreased very sharply, some sectors can still survive the covid-19 pandemic. Like the health sector that takes an important role to help the economic recovery in the Covid-19 pandemic such as masks, medical devices, and medicines that are needed at this time to support the recovery and healing for those who are infected with Covid-19. The Information and Communication Sectors that continue to improve the quality of the internet network to be needed for workers or education who work from home (WFH). Information and Communication Sector that continues to improve the quality of the internet network to be needed for workers or education who work from home (WFH). In addition to the health and Infocom sectors, there is also the agricultural sector, electricity and gas procurement, as well as the real estate sector which has survived during this pandemic, as seen from graph 1 of the economic growth of the business sector according to BPS. During the economic crisis caused by the pandemic, companies continue to pursue their economic, social, and environmental goals with more attention to the role they must play in society, But it is also necessary to pay attention to society and the environment as a whole (Chen \& Huang, 2019).

The COVID-19 outbreak has also shaken the domestic financial and stock markets. Based on Bloomberg data, at the close of trading on December 30, 2020, the IHSG weakened from 0.95 percent to 5,979.07. This indicates that the IHSG fell to its lowest level when compared to the end of 2019 at 6,299.54. Breaking the chain of the spread of Covid-19 with the implementation of the COVID-19 protocols has hit the real sectors in Indonesia. The value of the company is often associated with the stock market price, the higher the price of the company, and the higher the value of the company, so that investors easily decide to invest. A high company value will certainly cause the market to believe not only in the company's current performance but also in the company's prospects in the future. The movement of a company's value can be influenced by various factors, such as the condition of the company condition, economic and social conditions, and community conditions. Investors take the company's performance information in the social and environmental fields as consideration for investing in company shares.

The concept of CSR expresses the importance of joint efforts and helps companies to protect their reputation during the crisis. As a result of CSR practice, organizations enhance their abilities to restore business continuity, rapidly return to the normal, or quickly adapt to the changes (Gigauri, 2021). CSR strategies can be a useful and effective tool to deal with the global problems of the COVID-19 pandemic in the world (Sanchez, 2020). The research (Octoriawan \& Rusliati, 2019) shows that there is a positive relationship between corporate social responsibility and firm value. The research conducted (Muhlis \& Gultom, 2021) in BUMN enterprises in Indonesia that economic indicators do not affect the firm value, but environmental indicators CSR and social indicators CSR affect the firm value. As for the results of the study conducted by (Mariani \& Suryani, 2018), the Financial performance and social performance CSR affect the firm value, while environmental performance CSR does not affect the Firm Value. (Hossain et al., 2016) found that there was a non-significant relationship 
between CSR and Tobin's Q. (Sucuahi \& Cambarihan, 2016) and (Fatimah \& Sukardan, 2018) show that the relationship between profitability and firm value has a moderate relationship.

In this pandemic period, most companies have to reorganize all CSR project design plans prepared for the future, as the pandemic impacts the broader targets of CSR recipients (Akbar \& Humaedi, 2020). On this occasion, it should be utilized as well as possible by the company to get a good image back in the community (Oktina et al., 2020), One of the benefits that companies can get is if they can implement CSR well is the increasing image of the company. Because the objective of every company is to maximize the assets or firm value that is essential for a company because it is increasing the wealth. As for the rules governing Corporate Social Responsibility (CSR), It has started to grow since there was Undang-Undang No. 40 on 2007 pasal 74 about the Company that carries out its business activities in the field and/or related to natural resources must carry out Social and Environmental Responsibilities. Corporate social responsibility comes from the concept of the triple bottom lines, John Elkington (1994) presented this concept in his book 'Cannibals With Forks', which stated that the company must apply this concept in order for the company to develop sustainably. The Sustainbility Report of The Global Reporting Initiative (GRI) focuses on three aspects of performance: economic, environmental, and social. These three areas are called Triple Bottom Line (TBL). In this pandemic period, most companies have to reorganize all CSR project design plans prepared for the future, as pandemic outbreak has given massive impact the broader targets of CSR 'recipients. On this occasion, it should be utilized as well as possible by the company to get a good image back in the community (Oktina et al., 2020), One of the benefits that companies can get is if they can implement CSR well is the increasing image of the company. Because the objective of every company is to maximize the assets of firm value and maximize the firm value essential for the company which means increasing the wealth of shareholders as well (Sucuahi \& Cambarihan, 2016).

Supporting the theory of legitimacy, argue the relationship between profitability and the level of Corporate Social Responsibility (CSR) when a company's profit is high, the company does not need to report things that interfere with the company's financial success information. One of the successes of the company can be measured through good financial performance, it can be seen from the profit obtained by the company. This study measures the company's financial performance is using the profitability ratio. The profitability ratio is the ratio used for a company to measure how much the company's ability to seek profit (Kasmir, 2016). The research conducted by (Mohd Razali et al., 2018) and (Shoukat Malik \& Nadeem, 2014) show that there is a positive relationship between CSR and financial performance, reveals that a high level of CSR disclosure helps firms to achieve optimum performance through increased competitiveness, improved firm's image amongst society, and creates new opportunities in the market. According to (Pan et al., 2014) Corporate Social Responsibility affects the company's financial performance because it can help companies reduce expenses so that they focus on profit-oriented. The research conducted by (Hutagalung \& Harahap, 2016) stated that Corporate Social Responsibility Disclosure is measured using economic performance and environmental performance affecting profitability, while social performance does not affect its profitability either. However, the results of the research conducted by (Muslimah, 2018) that disclosure of economic performance, environmental performance, and social performance affects its profitability. Based on the above background, this study aims to examine and analyze the effect of corporate social responsibility as measured by economic performance, environmental performance, and social performance on firm value with financial performance as a mediating variable in public companies in Indonesia.

\section{METHOD}

This research used documentation techniques in data collection, it is done by collecting secondary data in the form of company annual reports containing information needed relating to the research. This study uses descriptive statistical analysis techniques by describing the data collected to make conclusions and statistical verification to test research hypotheses. Then, the analytical method in this study uses the PLS (Partial Least Square) approach. The PLS approach can be used for research that requires confirmation of the relationship between variables, PLS is also an analytical method that does not have a basis on which the number of samples must be at least 100 because in this study using a sample of 75, PLS does not question the normality of the data distribution because PLS does not concern about the number of samples below 100 samples. Therefore, PLS can be used in testing this research (Garson, 2016). The stages for PLS testing are to test the Outer Model, Inner Model, Model Fit Test, and Test of the Hypothesis.

The population in this study is the public company sector in Indonesia based on the industry code ISO that has a positive GDP value are the information and communication sector, the agricultural sector, the health sector, the real estate sector, and the electricity sector. The technique used to determine the sampling is purposive sampling with the following criteria: 
Table 1. Sample Criteria

\begin{tabular}{lc}
\hline \multicolumn{1}{c}{ Information } & Total \\
\hline $\begin{array}{l}\text { Public companies in Indonesia based on ISO industry codes that have a } \\
\text { positive GDP value (Infokom Sector, Health Sector, Agriculture Sector, }\end{array}$ & 118 \\
Electricity Sector, and Real Estate Sector) \\
Companies that do not publish annual reports during the $2019-2020$ \\
research period \\
Companies that have not done an IPO \\
Companies that did not make a profit during the 2019-2020 research period \\
Total Companies that meet the sampling criteria \\
Total Sample Number During Research Period 2019-2020 (35 x 2)
\end{tabular}

\section{RESULTS}

Testing descriptive statistical analysis to provide an overview of the variables used in this study.

Table 2. Overall Descriptive Statistical Test Results

\begin{tabular}{ccccc}
\hline & Minimum & Maximum & Mean & Std. Deviation \\
\hline Economic & 0,22 & 1.00 & 0,442 & 0,1657 \\
Environment & 0,15 & 0,59 & 0,3226 & 0,1124 \\
Social & 0,13 & 0,54 & 0,348 & 0,100975 \\
ROE & 0,26 & 51.77 & 10,8161 & 8,910291 \\
Tobin's Q & 0,15 & 6,96 & 1,588 & 1,367719 \\
\hline Source
\end{tabular}

Source: SmartPLS Output Results (2021)

Based on the result, It can be seen that the Corporate Social Responsibility variable as measured by Economic Performance has a mean of 0.442 and a standard deviation of 0.1657 . with a minimum value of 0.22 which is owned by Astra Agro Ali Tbk that is engaged in the agriculture sector, Royal Prima Tbk in the health sector, Bhuwanatala Indah Permai Tbk, Ciputra Development Tbk, Natura City Development Tbk, Intiland Development Tbk, Jaya Real Property Tbk in the real estate sector and a maximum value of 1.00 owned by Duta Pertiwi Tbk in the real estate sector. The Corporate Social Responsibility variable measured by its environment has a mean of 0.3226 and a standard deviation of 0.1124 , with a minimum value of 0.15 owned by Provident Agro Tbk that is engaged in the agriculture sector and Bumi Serpong Damai Tbk which is engaged in the real estate sector and a maximum value of 0.59 owned by Cikarang Listrindo in the electricity sector Tbk and Duta Pertiwi Tbk in the real estate sector. Then, the Corporate Social Responsibility variable was measured by Social Performance has a mean of 0.348 and a standard deviation of 0.100975 with a minimum value of 0.13 owned by Natura City Development Tbk in the real estate sector and a maximum value of 0.54 owned by PP Properti Tbk in the real estate sector.

Variable Financial Performance was measured by Return On Equity (ROE) has a mean of 10.8161 and a standard deviation of 9.910291 with a minimum value of 0.26 owned by Royal Prima Tbk in the health sector and a maximum value of 51.77 owned by Provident Agro Tbk in the agriculture sector.

The Firm Value was measured by Tobin's Q has a mean of 1.588 and a standard deviation of 1.367719 with a minimum value of 0.15 owned by Duta Pertiwi Tbk in the real estate sector and a maximum value of 6.96 owned by Mitra Keluarga Karya Sehat Tbk in the health sector. The overall variable results in this study show a standard deviation value that is smaller than the average value. This matter indicates that the distribution of variable data is small or there is no large enough gap between the lowest data and the highest data.

After conducting descriptive statistical analysis, the next is to perform an outer model analysis used to test the feasibility of measurements that can determine the validity and reliability of measurement. Based on Figure 2, the outer loading value for all indicators has a value of more than 0.70 , this indicates that the research can be accepted. The Validity test is conducted by measuring Croanbach's Alpha value $\geq 0.60$ and the Average Variance Extracted (AVE) value $\geq 0.50$ (Garson, 2016). Meanwhile, to determine the reliability of the analysis value using the expected composite reliability (CR) of $\geq 0.70$ (Garson, 2016). If all are met then the measurement can be mentioned to be valid and reliable. 


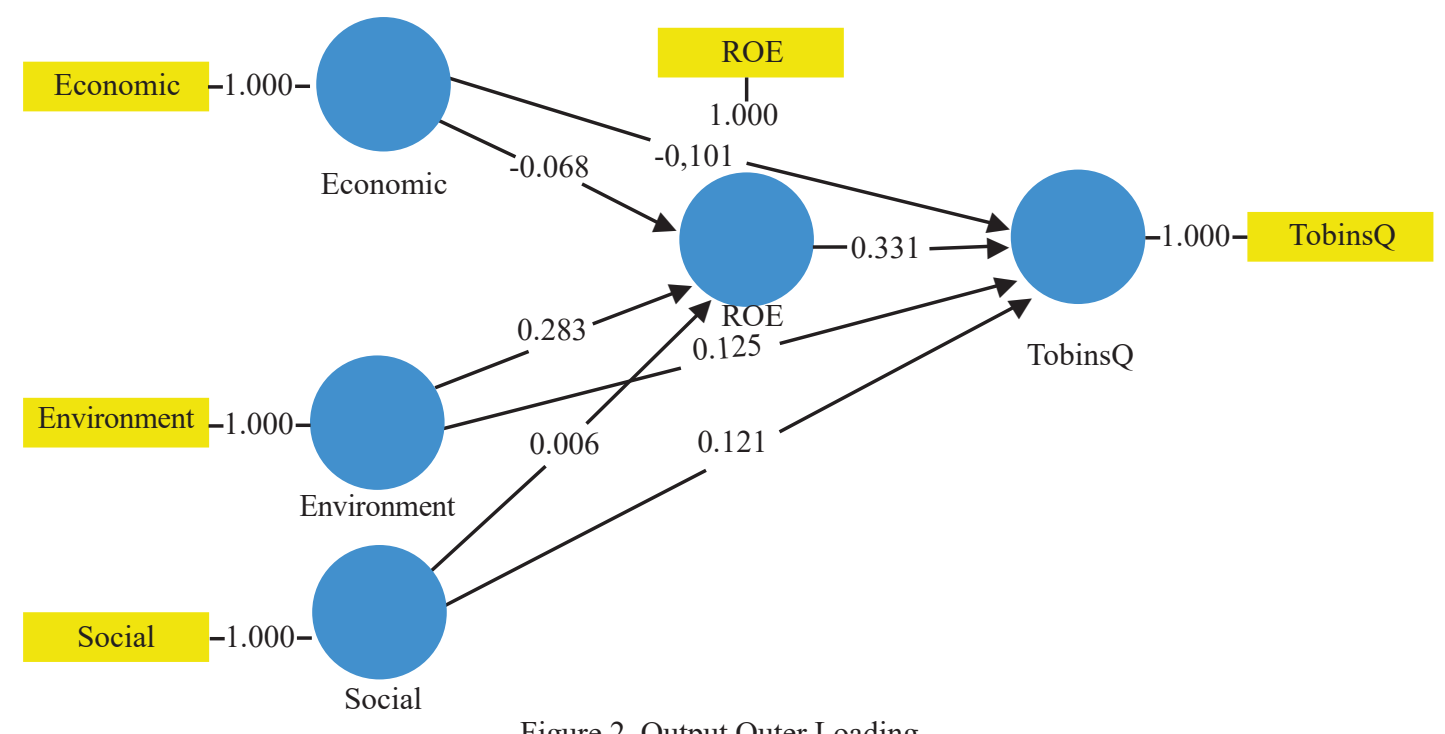

Figure 2. Output Outer Loading

Table 3. Cronbach's Alpha, Composite Reliability, and Average Variance Extracted (AVE)

\begin{tabular}{cccc}
\hline & CA & CR & AVE \\
\hline Economic & 1.000 & 1.000 & 1.000 \\
Environment & 1.000 & 1.000 & 1.000 \\
Social & 1.000 & 1.000 & 1.000 \\
ROE & 1.000 & 1.000 & 1.000 \\
\hline
\end{tabular}

Source: SmartPLS Output Results (2021)

Table 3 shows the results of Crobach's Alpha value has a value of more than 0.60 for the entire construct, the Average Variance Extracted (AVE) value of each construct has a value above 0.50 . Therefore, all variables in this research can be mentioned to be valid. Similarly, the Composite Reliability value has a value of more than 0.70 for the entire construct, thus all constructs meet reliable criteria following the recommended criteria and testing can be carried out to the next stage.

Inner model analysis can also be called an analysis of model structure used to prove tests that provide evidence of compatibility between previously hypothesized variables. The inner analysis of the model can be seen from the regression coefficient shown in the p-values column $(\alpha)$ of 0.05 or $5 \%$ and the t-statistics column with a significance value of $\geq 1.997$. Relationships between variables are said to have a significant effect if the values p-values $<$ the values of significance and t-statistics $>$ the value of significance. In addition, to the regression coefficient, the goodness of fit (GOF) is also used from the R square value and Stone Geisser Q2. Table 5 shows that the effect of economic performance, environmental performance, and social performance in return on equity (ROE) values can be interpreted at $5.5 \%$ and the remaining $94.5 \%$ can be explained by other variables outside the study. Furthermore, Tobin's Q value of $16.8 \%$ and the remaining $83.2 \%$ can be explained by other variables outside of this study. Meanwhile, the results of Stone Geisser Q2 of 0.218 , also showed that the structural model in the study was a good value because it was between the values of 0 (zero) and 1 (one) or $0<\mathrm{Q} 2$.

Table 4. Regression Coefficient

\begin{tabular}{cccc}
\hline & Original Sample & P-Values & T Statistic \\
\hline Economic -> ROE & $-0,014$ & 0,936 & 0,081 \\
Environment -> ROE & 0,205 & 0,259 & 1,130 \\
Social -> ROE & 0,054 & 0,663 & 0,436 \\
Economic -> Tobin's Q & $-0,098$ & 0,482 & 0,704 \\
Environment -> Tobin's Q & 0,068 & 0,710 & 0,372 \\
Social -> Tobin's Q & 0,124 & 0,491 & 0,689 \\
ROE -> Tobin's Q & 0,359 & 0,020 & 2,325 \\
\hline
\end{tabular}

Source: SmartPLS Output Results (2021) 
Table 5. R square value and Stone Geisser Q

\begin{tabular}{cccc}
\hline & R Square & R Square Adjusted & Q2 \\
\hline ROE & 0,055 & 0,012 & 0,218 \\
Tobin's Q & 0,168 & 0,113 & \\
\hline
\end{tabular}

Source: SmartPLS Output Results (2021)

\section{DISCUSSION}

First, Economic performance does not affect the return on equity (ROE). This indicates a discrepancy with stakeholder theory, there is a lack of harmony of the company to its environment on economic issues. In this pandemic period, the company is required to reorganize all its activities related to the economy because it is to maintain the company's defense in the future. According to (Hutagalung and Harahap, 2016) Companies that disclose economic performance reporting in sustainability reports will increase the company's transparency which has an impact on improving investor confidence and financial performance. The results of this research are supported by the research conducted by (Hutagalung and Harahap 2016) and (Muslimah, 2018).

Second, Environmental Performance does not affect Return on Equity (ROE). In this condition, there is a covid-19 pandemic that threatens the economy in companies in Indonesia that causes sustainability disclosure to be an over-the-top priority. There is a lack of legitimacy theory where the company is still not oriented to stakeholders such as the public, suppliers, investors. This is because the disclosure of environmental performance made by the company becomes an additional cost for the company and the cost affects the reduction of capital used by the company for financing. The results of this study are in line with research conducted by (Muslimah 2018) ; (Singh, 2016); and (Karyawati et. al 2017).

Third, Social Performance does not affect Return on Equity (ROE). There is a discrepancy between the theory of legitimacy in which the management of the company must be oriented to partialities such as the community, government, individuals, and investors to get support from interested parties that affect the company's operations. In addition, the lack of understanding of corporate social responsibility increases investor interest in investing because the company concerns about its stakeholders such as being responsible for products and services, involving local communities for the development of the company. This research is in line with the research conducted by (Karyawati et. al., 2017) and (Hutagalung and Harahap, 2016).

Fourth, Economic performance does not affect the firm value. The disclosure of economic performance carried out by companies voluntarily has not become an information requirement by investors to make decision making, this indicates that investors are more likely to see financial information generated by the company because it can provide a high increase in the value of the company compared to non-financial information disclosed by the company. There is a discrepancy with stakeholder theory, where disclosures disclosed sustainably are expected to have a good impact on the survival of the company and get support from stakeholders. Companies need to provide relevant information to stakeholders about the position, efforts, and achievements of corporate social and environmental responsibility through CSR disclosure. The results of this research are in line with the research conducted by (Muhlis \& Gultom, 2021) and (Sejati and Prastiwi, 2015).

Fifth, Environmental Performance does not affect the Firm Value. The higher the company reveals the environmental performance that the impact of the company on the environment around the company which includes materials, energy, water, ecosystems, emissions, and waste cannot enhance the company's image. In these conditions, companies should try to take advantage of the situation to get attention from the public through their concern for the environment following stakeholder theory, however, the company has not fully done so due to a lack of understanding of environmental concerns. Companies that perform less well tend to reveal less information about their environmental performance. (Mariani and Suryani, 2018). Concerning stakeholder theory, companies that have a high level of environmental performance will be responded positively to stakeholders (investors) through fluctuations in stock prices. The results of this research are in line with (Sejati and Prastiwi 2015) and (Mariani and Suryani, 2018).

Sixth, Social Performance does not affect the Firm Value. The results of this study allegedly do not support the legitimacy theory that reveals that companies are continuously seeking to act within the boundaries and norms in society. According to (Sejati and Prastiwi, 2015) companies that disclose social performance can have a competitive advantage that is not proven. Disclosure of social performance is only formal information and cannot attract investors with information about the company's concern for services and products, to the community around the company, to build consumer loyalty that can increase sales. The results of this research are in line with the research conducted by (Sejati \& Prastiwi, 2015). 
Finally, Return on Equity (ROE) affects the Firm Value. Companies that have a good level of performance, can provide an increase in the value of their company or a positive return response from stakeholders because a company that has good performance is an achievement that has been achieved by the company. Following the signal theory, companies that produce good performance have a high incentive to provide information to external parties, because each stakeholder is entitled to information on the company's operational activities to make decisions to invest their capital. Companies that maintain good relations with their stakeholders by meeting the needs of their stakeholders such as financial information needed will get a good image from the views of stakeholders so that investors believe and do not hesitate if they invest in the company because the company is considered able to return its invested capital, the higher the level of profit that the company generates, and the higher the attractiveness of such investors to the company because the company has managed its capital effectively and efficiently. The results of this research are in line with the research conducted by (Triagustina et al., 2014); (Fatimah \& Sukardan, 2018); (Sucuahi \& Cambarihan, 2016); and (Tauke et al., 2017)

\section{CONCLUSION}

This research aims to analyze the influence of Corporate Social Responsibility (CSR) disclosure measured by indicators of economic performance disclosure, environmental performance, and social performance on financial performance and firm value in public companies in Indonesia in the sector information and communication, health services sectors, agriculture sectors, electricity procurement sectors, and real estate sectors. The results of this research show that economic performance, environmental performance, and social performance are still not able to show the company's ability to generate profit when viewed from profitability and have not improved the company's image. This is because of the company's concern or lack of understanding of corporate social responsibility, and stakeholders need more financial information than non-financial. Therefore, the importance of companies in Indonesia is to take advantage of the current situation to improve the company's image by prioritizing sustainability disclosure activities due to the legal regulations governing it. Furthermore, the disclosure of return on equity (ROE) can demonstrate a company's ability to improve the company's image. This is important that stakeholders urgently need the company's financial information in terms of managing its capital, following the signal theory if the positive signal is given to stakeholders then positive returns will also be obtained by the company.

\section{REFERENCES}

Akbar, U. R., \& Humaedi, S. 2020. Peran CSR Dalam Upaya Mengatasi Pandemi Covid-19. Prosiding Penelitian Dan Pengabdian Kepada Masyarakat, 7(2), 341. https://doi.org/10.24198/jppm.v7i2.28874

Chen, Y., \& Huang, Y. 2019. The Impact of Triple Bottom Line-Oriented Environmental Management System on Firms Performance in China: Evidence from Yangtze River Delta. FEMIB 2019 - 1st International Conference on Finance, Economics, Management and IT Business, Femib, 60-69. https://doi. org/10.5220/0007738600600069

Elkington, J. 1994. Towards the Sustainable Corporation: Win-Win-Win Business Strategies for Sustainable Development. California Management Review, 36, 90-100.

Fatimah, \& Sukardan, D. 2018. CSR Disclosure, Profitability and Solvency. Jurnal Riset Akuntansi Kontemporer, 10(2), 99-103.

Garson, G, D. 2016. Partial Least Squares: Regression \& Structural Equation Models.

Gigauri, I. 2021. Corporate Social Responsibility and COVID-19 Pandemic Crisis. International Journal of Sustainable Entrepreneurship and Corporate Social Responsibility, 6(1), 30-47. https://doi.org/10.4018/ IJSECSR.2021010103

Hossain, M., Chowdhury, M. H., Evans, R., \& Lema, A. C. 2016. The Relationship Between Corporate Social Responsibility and Corporate Financial Performance - Evidence from Empirical Studies. Corporate Ownership \& Control, 12(3), 474-487. https://doi.org/10.1515/cer-2016-0030

Hutagalung, A., \& Harahap, K. 2016. Pengaruh Pengungkapan Sustainability Report Terhadap Profitabilitas Perusahaan Manufaktur Yang Terdaftar Di Bursa Efek Indonesia Periode 2009-2012. Jurnal Akuntansi, Keuangan \& Perpajakan Indonesia, 03(1), 1-14.

Karyawati, N. N. A., Yuniarta, G. A., \& Sujana, E. 2017. Pengaruh Tingkat Pengungkapan Laporan Keberlanjutan terhadap Kinerja Keuangan Perusahaan. Jurnal Akuntansi Universitas Pendidikan Ganesha, $7(1), 1-10$. 
Kasmir. 2016. Analisis Laporan Keuangan. Rajawali Pers.

Mariani, D., \& Suryani, S. 2018. Pengaruh Kinerja Keuangan Terhadap Nilai Perusahaan Dengan Kinerja Sosial dan Kinerja Lingkungan Sebagai Variabel Moderator (Studi Empiris Pada Perusahaan Pertambangan dan Manufaktur yang Terdaftar di Bursa Efek Indonesia Tahun 2011 - 2015). Jurnal Akuntansi dan Keuangan, 7(1), 59-78.

Mohd Razali, M. W., Sin, W. H. S., Lunyai, J. A., Hwang, J. Y. T., \& Md Yusoff, I. Y. 2018. Corporate Social Responsibility Disclosure and Firm Performance of Malaysian Public Listed Firms. International Business Research, 11(9), 86-95. https://doi.org/10.5539/ibr.v11n9p86

Muhlis, \& Gultom, K. S. 2021. Pengaruh Pengungkapan Corporate Social Responsibility Terhadap Nilai Perusahaan BUMN Sektor Pertambangan. Jurnal Ilmiah Akuntansi Kesatuan, 9(1), 191-197.

Muslimah, H. S. 2018. Pengaruh Pengungkapan Sustainbility Report Terhadap Kinerja Perusahaan (Studi Empiris Pada Perusahaan Non-Keuangan Yang Terdaftar Di Bursa Efek Indonesia Tahun 2013-2016). In Angewandte Chemie International Edition, 6(11), 951-952. Universitas Islam Indonesia.

Octoriawan, A., \& Rusliati, E. 2019. Corporate Social Responsibility, Kepemilikan Manajerial Terhadap Nilai Perusahaan Dengan Moderasi Ukuran Perusahaan. Jurnal Riset Akuntansi Kontemporer, 11(2), 60-68. https://doi.org/10.23969/jrak.v11i2.2771

Oktina, D. A., Sari, E. S., Sunardi, I. A., Hanifah, L. N., \& Sanjaya, V. F. 2020. Pengaruh Penerapan Strategi CSR (Corporate Social Responsibility) dalam Meningkatkan Citra Perusahaan Pada PT Pertamina (Persero) Tahun 2018. Competence : Journal of Management Studies, 14(2), 184-202. https://doi. org/10.21107/kompetensi.v14i2.8962

Pan, X., Sha, J., Zhang, H., \& Ke, W. 2014. Relationship Between Corporate Social Responsibility and Financial Performance in The Mineral Industry: Evidence from Chinese Mineral Firms. Sustainability (Switzerland), 6(7), 4077-4101. https://doi.org/10.3390/su6074077

Sanchez, I. M. G. 2020. Corporate Social Responsibility During COVID-19 Pandemic. Journal of Open Innovation: Technology, Market, and Complexity, 6(4), 1-21. https://doi.org/10.3390/joitmc6040126

Sejati, B. P., \& Prastiwi, A. 2014. Pengaruh Pengungkapan Sustainability Report Terhadap Kinerja dan Nilai Perusahaan. Diponegoro Journal of Accounting, 0(0), 195-206.

Shoukat Malik, M., \& Nadeem, M. 2014. Impact of Corporate Social Responsibility on The Financial Performance of Banks in Pakistan. International Letters of Social and Humanistic Sciences, 21, 9-19. https:// doi.org/10.18052/www.scipress.com/ilshs.21.9

Singh, S. 2016. Impact of Corporate Social Responsibility Practice on Return on Equity : A Study of Nifty Companies. International Journal of Business Quantitative Economics and Applied Management Research, 3(3), 23-32.

Sucuahi, W., \& Cambarihan, J. M. 2016. Influence of Profitability to The Firm Value of Diversified Companies in The Philippines Preference of Short-Term Traders View Project Influence of Profitability to The Firm Value of Diversified Companies in the Philippines. Accounting and Finance Research, 5(2). https:// doi.org/10.5430/afr.v5n2p149

Tauke, P. Y., Murni, S., \& Tulung, J. E. 2017. Pengaruh Kinerja Keungan terhadap Nilai Perusahaan Real Estate dan property yang terdaftar di Bursa Efek Indonesia Tahun 2012-2015. Jurnal EMBA, 5(2), 919927.

Triagustina, L., Sukarmanto, E., \& Helliana, H. 2014. Pengaruh Return On Asset (ROA) dan Return On Equity (ROE) Terhadap Nilai Perusahaan Pada Perusahaan Manufaktur Subsektor Makanan dan Minuman yang Terdaftar di Bursa Efek Indonesia Periode 2010-2012. Prosiding Akuntansi, 28-34. 